Review

\title{
Solid Dispersions of Anthelmintics and Plant Protection Preparations
}

\author{
Salavat S. Khalikov
}

check for

updates

Citation: Khalikov, S.S. Solid Dispersions of Anthelmintics and Plant Protection Preparations. Solids 2021, 2, 60-75. https://doi.org/ $10.3390 /$ solids 2010003

Received: 13 January 2021

Accepted: 3 February 2021

Published: 6 February 2021

Publisher's Note: MDPI stays neutral with regard to jurisdictional claims in published maps and institutional affiliations.

Copyright: (C) 2021 by the author. Licensee MDPI, Basel, Switzerland. This article is an open access article distributed under the terms and conditions of the Creative Commons Attribution (CC BY) license (https:// creativecommons.org/licenses/by/ $4.0 /)$.
A.N. Nesmeyanov Institute of Elementoorganic Compounds Russian Academy of Sciences, 119991 Moscow, Russia; khalikov_ss@ineos.ac.ru

\begin{abstract}
Because of the rapid development of nanotechnologies, materials, in particular, solid dispersions (SDs), which are actively introduced into the life of modern man, have been obtained. Special progress in this area is observed in industry and medicine. The use of SDs in agriculture is lagging far behind, despite the growing number of scientific papers on this topic. At the same time, the prospects for the introduction of SDs in the agro-industrial complex are obvious. The review presents the results of research on the development of innovative preparations based on SD to protect plants from diseases and pests of cultivated plants, as well as parasiticides to protect animal health based on modern achievements of nanotechnology. One of these technologies is the methods of mechanochemistry, which improve the properties of poorly soluble biologically active substances by their joint mechanical treatment with water-soluble polymers and auxiliary substances.
\end{abstract}

Keywords: solid dispersions; anthelminthics; plant protection; solubility; mechanochemistry

\section{Introduction}

Increasing the solubility of poorly water-soluble drugs remains one of the most challenging aspects of drug development. The solubility of active substances (AS) is a step that determines the rate of oral absorption of the drug, which can subsequently affect the absorption of this drug. Because of the problem of solubility, many drugs have low bioavailability and, therefore, increasing the solubility of low-soluble AS becomes a very urgent task. Accordingly, solid dispersions (SD) is one of the most attractive objects for improving the solubility of AS, and they are finely dispersed powders, ideally nanopowders, consisting of a hydrophilic matrix (water-soluble polymers and excipients) and a hydrophobic drug (possibly several AS). Therefore, the SD of some drugs were announced as a new dosage form of drugs and they are already used in medical practice $[1,2]$ :

- $\quad$ Sporanox ${ }^{\circledR}$ (itraconazole)

- $\quad$ Intelence $^{\circledR}$ (etravirine)

- Prograf $^{\circledR}$ (tacrolimus)

- $\quad$ Crestor $^{\circledR}$ (rosuvastatin)

- $\quad$ Gris-PEG ${ }^{\circledR}$ (griseofulvin)

- $\quad$ Cesamet $^{\circledR}$ (nabilone)

Solid dispersion was first used in pharmacy to improve the solubility of AS, since they were an effective means of increasing the rate of dissolution and, consequently, the bioavailability of drugs [3,4]. Such systems are used:

- $\quad$ to enhance the absorption of the drug;

- $\quad$ to obtain a uniform distribution, a small amount of the drug in the solid state;

- $\quad$ to stabilize unstable drugs and protect against decomposition by processes such as hydrolysis, oxidation, racemization, photo-oxidation, etc.;

- for dosing liquid or gaseous compounds;

- $\quad$ for the preparation of a primary dose with a rapid release in a drug form with a delayed release; 
- $\quad$ for composing a drug of soluble drugs with delayed release by dispersing the drug in a poorly soluble or insoluble carrier;

- $\quad$ to reduce side effects (a) the binding capacity of drugs, (b) damage to the gastric mucosa by some non-steroidal anti-inflammatory drugs;

- to mask the unpleasant taste and smell of AS; and,

- $\quad$ for converting liquid compounds into formulations.

\section{Solid Dispersions: Methods of Preparation, Properties, Application}

It is known that $\mathrm{SD}$ is the dispersion of one or more active ingredients in a carrier or matrix in a solid state. There are various methods for obtaining SD, which can be divided into the following [5]:

- $\quad$ varieties of methods using organic solvents (Kneading Method, Solvent melting method, Spray-Drying Method, Gel entrapment technique);

- $\quad$ the methods of Melting/Fusion method;

- $\quad$ the method of hot extrusion;

- the method of co-grinding; and,

- $\quad$ the method of supercritical fluid.

Usually, SD are widely used in medicine [6-10], because these systems can provide many additional advantages:

1. to increase the solubility of poorly soluble drugs, thereby increasing the rate of dissolution, absorption, and bioavailability;

2. to improve the drug output of ointments creams and gels;

3. to avoid undesirable incompatibilities;

4. to obtain a uniform distribution of a small amount of the drug in the solid state;

5. to formulate the primary dose of rapid release in a long-release dosage form;

6. to formulate a regime of prolonged release of soluble drugs using poorly soluble or insoluble carriers; and

7. to reduce pre-systemic inactivation of drugs such as morphine and progesterone.

The disadvantages of SD drugs [11] are the following factors:

- $\quad$ polymers used in SD can absorb moisture, which can lead to phase separation, crystal growth, or transition from an amorphous to a crystalline state or from a metastable crystalline form to a more stable structure during storage. This can lead to a decrease in the solubility and dissolution rate;

- many water-soluble polymers show excellent results in enhancing the dissolution of drugs, but to achieve high efficiency, a large amount of them is used (from 50 up to $90 \%$ ), which is economically unjustified;

- due to the fact that SD is a high-energy metastable form, phase separation, crystal growth, or transformation from an amorphous form to a crystalline one is possible during storage, which reduces solubility and dissolution rate and leads to variable oral bioavailability;

- $\quad$ some technologies (in particular, melting and/or hot extrusion methods) lead to a decomposition of the active substance and, therefore, are not acceptable for a wide range of labile and low-melting substances; and,

- most methods involve the use of solvents that are toxic, flammable, and require the complete removal from the final product to form a large amount of waste.

Based on the results of the use of SD to improve the properties of AS, the following prospects for the use of SD in the field of medicine are determined [11,12]:

- despite the many advantages of SD, their commercialization is limited due to the complexity and high cost of production processes, reproducibility, complexity of formulations, scaling, and stability. In this direction, there are prospects for further research;

- there are successes in the development of SD for preclinical, clinical, and commercial use due to the inclusion of surfactants and self-emulsifying carriers with relatively low melting points in the formulations; and, 
- promising methods for obtaining SD will be methods that exclude the use of solvents.

Thus, the above statement allowed for stating that $\mathrm{SD}$ is used quite widely in medicine and there are many reviews about this, in addition to research articles [2-5,13-16]. However, the use of SD for improving plant protection products, in particular, in the development of innovative protectants for cereals and potatoes, does not have the same great achievements, namely, only a few studies on the use of nanopesticides in the field of plant protection are known [17-20]. These preparations do not represent SD and they are obtained by nanotechnology methods, mainly from inorganic materials in the form of nanoparticles, carbon tubes, etc. Modern capabilities of nanotechnology allow for producing pesticides in the form of nanoparticles, which significantly reduces the impact of agricultural products on human health and the environment.

As for the use of SD in the field of animal health protection, namely, the use of SD to improve the properties of anthelmintics, few such works are known. These include, for example [21], in which a composition SD of two components (albendazole /ABZ/ and hydroxypropyl $\beta$-cyclodextrin) in molar ratio of 1:1 contributed to an increase in the bioavailability of ABZ by $40 \%$ as compared to its suspension form (Table 1). Continuing these studies, the authors [22] obtained a SD of the composition ABZ:hydroxypropyl $\beta$ cyclodextrin:L-tartaric acid (molar ratio 1:1:1), which was absorbed even faster than the known SD of two components, which was reflected in the improvement of anthelmintic efficacy against Trichinella spiralis (Table 1) At the same time, to obtain the target SD of the composition of the ABZ:PVP (1:1) dissolution method was used, namely, the components were dissolved in methanol with stirring for $24 \mathrm{~h}$ and the resulting solution was poured on Teflon sheets. The solvent was removed by evaporation in a partially open desiccator at room temperature for three days. The resulting films were carefully ground to a powdery state and dried under vacuum at room temperature for $24 \mathrm{~h}$ and at $40{ }^{\circ} \mathrm{C}$ for $12 \mathrm{~h}$ [23]. From the above, it can be seen that this technology is quite time-consuming and it includes the processes of dissolution, evaporation of methanol, drying, and grinding of polymer films, which is especially time-consuming, and can lead to the destruction of labile molecules and to large losses with the formation of waste.

Another example of the use of SD for veterinary medicine can be considered [24] to increase the effectiveness of the low-water-soluble drug mebendazole (MBZ) by the lyophilization method. Solid dispersions of MBZ containing different proportions of lowsubstituted hydroxypropylcellulose were obtained (Table 1). In vivo efficacy was evaluated using studies of anthelmintic activity against the enteral stage of Trichinella spiralis in mice and it was shown that the anthelmintic effect of SD was significantly increased as compared to the initial MBZ. Dissolution studies have shown a marked increase in the rate of dissolution when compared to the initial MBZ. A significant improvement in the rate of dissolution of MBZ from solid dispersions was associated with a decrease in the crystallinity of the drug and a change in the surface morphology, as well as with the effect of wetting the polymer.

Given that oral bioavailability is the main problem when a poorly water-soluble active agent is orally delivered, a number of studies have been conducted, which are presented in the review [25]. Solid dispersion systems for a number of drugs, including animal health products, have been demonstrated.

For the poorly water-soluble drug ketoconazole $(\mathrm{KC})$, the corresponding SD was obtained (Table 1) by the extrusion of a melt with a copolymer of polyvinipyrrolidone 17 (PVP 17) and PVP-vinyl acetate (PVP-VA64) [26]. The methods of physical and chemical studies showed a homogeneous spatial distribution of $\mathrm{KC}$ in the polymer without chemical interaction of the drug with the polymer. The features of SD dissolution and the rate of $\mathrm{KC}$ release from SD were also studied. The authors concluded that the inhibition of particle growth during dissolution may be an important factor in achieving all of the benefits of enhanced dissolution of solid dispersions.

For the well-known anthelmintic praziquantel (PZQ), a combination of mechanochemical activation and spray-hardening (SH) technology for the treatment of schistosomal 
infections in children was proposed [27]. By the method of mechanical activation of PZQ with PVP at a mass ratio of 1:1, a polymer form was prepared in a vibrating mill under cryogenic conditions, which was loaded into microparticles while using SH-technology (Table 1). An analysis of the physico-chemical properties of the obtained SD showed an improvement in particle morphology, wettability, solubility, and an increase in biopharmaceutical properties. The review provides more in-depth studies on praziquantel SD for their use in medicine and veterinary medicine [28].

The technology of mechanochemical modification of poorly soluble substances with water-soluble polymers during their joint mechanical processing in grinders with controlled energy intensity (ball roll and planetary-centrifugal mills [29,30]) is proposed as an alternative innovative method for obtaining SD. The Figure 1 shows schematically possible ways of transformation of the initial components during their joint machining [31]. At the first stage, the initial components (pure soluble substance/dispersed phase/and water soluble polymer/dispersion medium/) are crushed and simultaneously mixed to form a homogeneous physical mixture with particle sizes up to 20-50 microns (called grinded powder). Usually in pharmacy at this stage, homogeneous powders are obtained, which are then used for the preparation of various dosage forms (tablets, powders, granules, etc.) [32]. During the further process of joint grinding, aggregates of micronized particles are formed, since the adhesion forces exceed the forces of particle destruction. SDs are formed at this stage [33]. Further mechanical processing of the components leads to mixing at the molecular level, when small particles of the drug (in the limit of the molecule and their aggregates) are distributed in the internal pores of the polymer, i.e., mixing occurs at the molecular level. In this case, the following options are possible:

1. if the components are not capable of chemical interaction, solid solutions with increased solubility and biological activity are formed [31,33];

2. when dissolved in water, these SDs form intermolecular, supramolecular, and inclusion complexes [29,34,35]; and,

3. if the initial components are capable of chemical interaction, then solid-phase mechanochemical reactions occur with the formation of interaction products [36,37].

\section{Mechanochemical transformations in mixtures of organic solids}

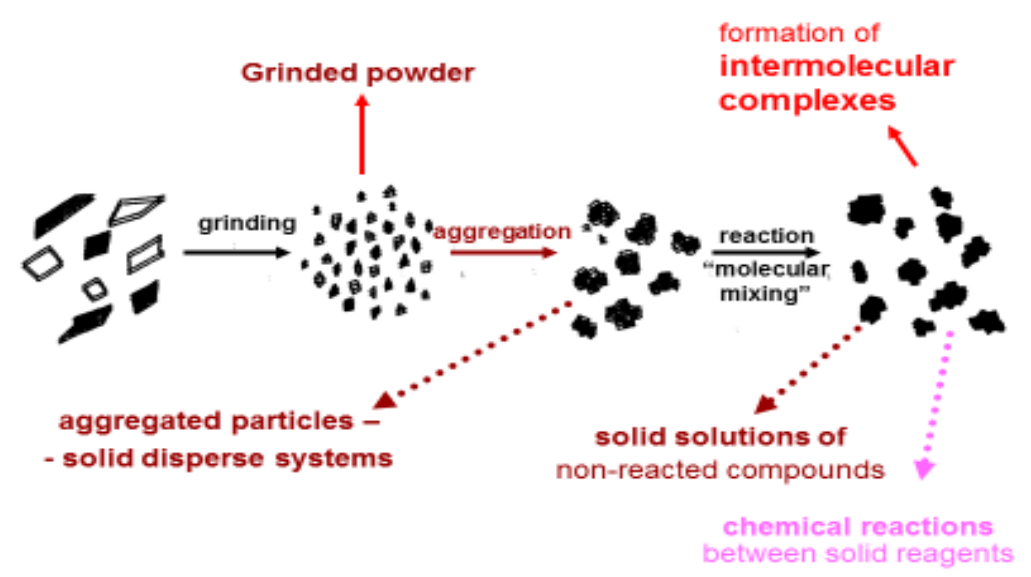

Figure 1. Scheme of mechanochemical transformations in mixtures of solids (AS + polymer) during their joint mechanical processing by impact-abrasion effects.

All of these processes belong to the objects of study of Mechanochemistry. These transformations allowed obtaining materials with unusual properties and conducting mechano-chemical synthesis.

The essence of mechanochemical technology is to obtain SD poorly soluble substances with auxiliary substances of various chemical nature. An increase in the solubility of substances is achieved: 
- due to the formation of SD, in which nanoparticles of low-molecular substances are dispersed in molecular form or are in an amorphous state; and,

- due to the formation of water-soluble inclusion complexes with polysaccharides when the obtained SD is dissolved in the form of biologically active media.

When solving the set tasks, the authors had to keep in mind the features of the physicochemical properties of the initial poorly soluble substances, polymers, and other excipients, as well as the objectives of the study. If for high-melting substances, the harsh conditions of solid-phase mechanochemical treatment were acceptable, then, for low-melting substances, they were pre-treated with a large volume of polymer or liquidphase treatment in water or a mixture of solvents to remove the negative effects of local overheating during mechanical processing.

The purpose of this review is to present the literature data and results of the author's own mechanochemical studies with colleagues, in order to show the potential of SD for creating promising anthelmintics for animals and protectants against diseases and pests. Data on obtaining, analyzing the properties, and prospects for applying the obtained SD will be presented to solve this problem.

\section{Solid Dispersions of Anthelmintics for Animal Health}

For the first time, the use of SD for veterinary medicine was reported back in 1995 [38], when the original technology of mechanochemical modification by joint solid-phase treatment of the anthelmintic substance medamine (solubility in water $1 \mathrm{mg} / \mathrm{L}$ ) with apple pectin in the planetary-centrifugal activator AGO-2 was obtained SD, named "medapec" with increased water solubility (45 mg/L) (Table 1). Medapec, while maintaining high activity against nematodes, showed high efficiency and a good tolerance in the model of larval echinococcosis of white rats, which is the closest to the corresponding human pathology $[39,40]$. This activity was explained by the formation of the corresponding inclusion complex in water from SD. This conclusion was done based on learning the IR spectroscopy data, dissolution, and dialysis methods of SD Medapec. The formation of similar inclusion complexes was confirmed on the basis of the IR spectra of SD carbendazim (synonym:medamine), ABZ, fenbendazole (FBZ), and triclabendazole (TCB) with PVP and Arabinogalactan (AG) [35]. Under similar conditions, the medamine substance was subjected to joint mechanical treatment with Microcrystalline cellulose (MCC) [41,42], with plant proanthocyanidines [43], and the corresponding SD were obtained, which had increased solubility in water, better permeability through model semipermeable membranes, and, hence, increased bioavailability.

Expanding the spectrum of benzimidazole anthelmintics [44], the substances of ABZ, FBZ, TCB, and their mixtures were selected, which were modified with such polymers as PVP, polysaccharides (AG, Glycyrrhizic acid/GA/and its derivatives, Hydroxyethyl Starch/HES/etc.), and auxiliary substances (silica gel, others) (Table 1). The machining of the components was carried out in a metal drum with steel balls in an LE-101 roller mill (manufactured in Hungary) and the corresponding SD were obtained, which were characterized by X-ray and DSC analysis, SEM, IR-spectroscopy, and dissolution in water [45-50].

Solid Dispersions of ABZ with AG from larch wood Larix sibirica and Larix gmelinii were obtained and investigated the physicochemical properties of them in solid state and in aqueous solutions as well as their anthelmintic activity against Trichinella spiralis, Hymenolepis nana, Fasciola hepatica, and mixed nematodoses of sheep [29,45]. The evidence of the inclusion complexes formation was obtained by intrinsic solubility and NMR relaxation technique. It was shown that mechanochemically synthesized SD are more stable as compared to the complex that was obtained by mixing solutions of the components. SD of ABZ show anthelmintic activity in 10 times reduced doses when compared with free ABZ and they also have a reduced acute toxicity and hepatotoxicity. These results substantiate the possibility of design new drugs on the basis of SD with composion ABZ:AG (1:1) with increased activity and safety of albendazole. The toxicity of SD was significantly less than that of ABZ, and it had a hepatoprotective effect due to the presence of AG in its 
composition. These results indicate that the SD of ABZ with AG is a potential candidate for therapy [46].

The SD of FBZ with PVP were synthesized using the same mechanochemical technology [47]. Physicochemical studies confirmed the increase in solubility of SD, the reduction of particle sizes, amorphization of FBZ substance, and incorporating it with micelles of PVP. The efficacy of SD was studied on the laboratory model of Hymenolepis nana and Trichinella spiralis infection of mice and helminthosis of sheep, and was shown that SD of FBZ with PVP was more active than the basic substance of FBZ and its anthelmintic properties were expanded. Thus, the mechanochemically obtained SD of FBZ with PVP polymer can serve as a basis for creating innovative drugs for the treatment of helminthosis in reduced doses [48].

The effect of mechanochemical technology on the anthelmintic efficacy SD of ABZ with extract of Licorice (EL), which is considered to be a means of targeted delivery [49]. Some SD were obtained by mechanochemical technology in the ratio ABZ:EL (1:20) in the form of a light brown powder (SD-1). Similarly, the SD were obtained in the ratio of ABZ:EL (1:10) (SD-2), in ratio ABZ:EL (1:9) (SD-3), and in the ratio of ABZ:EL (1:4) (SD-4). A significant change in this indicator was established in studying the solubility in water of the substance ABZ and their SDs, as well as suspensions based on these SD. The SD-3 had a 17 times increased solubility after three hours of machining. With an increase in the share of ABZ (from 10\% to 20\%) in SD-1 and SD-1, the solubility decreased to 13 times. The greatest increase in solubility was observed while producing the drug in the form of a suspension. In a physical mixture, the solubility of ABZ only increases three times. In experiments on sheep that were naturally infected with Nematodirusis and other species of Strongylates of the digestive tract and Moniesia, it was shown that all SD at a dose of $2.0 \mathrm{mg} / \mathrm{kg}$ of AS showed $90.1-91.7 \%$ efficacy against Nematodirus spp. and $89.5-92.4 \%$ efficacy against other types of gastrointestinal strongylates and $98.6-100 \%$ efficacy against Moniiesa expansa, which is $4-5$ times higher than ABZ activity.

By using the above-mentioned mechanochemical technology, $10 \mathrm{SDs}$ based on the substance of TCB with various water-soluble polymers (HES, PVP, AG, NaCMC) and some auxiliary $\left(\mathrm{SiO}_{2}\right)$ have been developed without the participation of liquid phases in one stage [50]. These SD are finely dispersed, easily free-flowing, water-soluble powders with a particle size of up to 1-10 microns (Table 1). In this case, the increase in the solubility of the obtained SDs ranged from three to 25 times, depending on the nature of the polymer, and the highest solubility was observed for SD of TCB:AG (1:9), which is called Triclafascid. Polysaccharide AG included in the composition of the preparation, isolated from Siberian larch, is widely used in medicine and veterinary medicine [51]. Because Fascioliasis, localized in the bile ducts, cause their thickening, fatty degeneration, and cirrhosis of the liver, and AG, possessing noticeable hepatoprotective and membranotropic properties, provide a high bioavailability of Triclafascid to parasites [52].

Another SD of FBZ with EL and sodium dioctylsulfosuccinate (DSS) is prepared by joint mechanochemical treatment in the ratio 1:8.9:0.1 [53]. The formation of SD was confirmed by observing an increase in the solubility up to 27 times; meanwhile, the solubility of the physical mixture only increased up to 2.6 (Table 1). Studying the X-ray and IR-spectra showed that the FBZ particle size decreased, and the FBZ lost crystallinity and acquired an amorphous character; however, no destructive alterations to the FBZ molecule due to mechanical processing were noticed. FBZ is likely to be found on the surface and inside the pores of EL and DSS molecules, which alters the properties and behavior of the active ingredient, and carriers transport it through cellular membranes. Based on the obtained results, it was confirmed that the enhancement in anthelminthic action is related to the smaller size of FBZ, a loss of crystallinity, amorphization, and inclusion of its molecules on the surface and inside the pores of polymers, and, as a consequence, an increase in solubility and permeability through biological membranes [54].

FBZ was also mechanically modified with AG and the resulting SD had an increased (in 18 times) solubility and a reduced dose of $3.0 \mathrm{mg} / \mathrm{kg}$ for AS shows $100 \%$ efficiency 
in Dictyocaulosis, Strongyloidosis, and Strongylatosis of the digestive tract and $98.3 \%$ activity in sheep Trichocephalosis [55], while the recommended dose of the standard drug is $5.0 \mathrm{mg} / \mathrm{kg}$ of AS (Table 1). However, the SD of FBZ with PVP and DSS had the solubility increased up to 24 times, which made it possible to achieve $100 \%$ efficiency in Trichinosis and Hymenolepiasis in white mice and gastrointestinal Strongylatosis and Moniesiasis in sheep at a dose of 2.0 and $3.0 \mathrm{mg} / \mathrm{kg}$, which is lower than the recommended dose of the standard drug [56].

The versatility of the mechanochemical modification technology was shown by expanding the spectrum of anthelmintics to other classes of organic compounds (praziquantel/from isoquinolines/; niclosamide/from salicylanilides/).

Niclosamide (NS) is widely used for the treatment of cestode infection in animals, and to increase its solubility, it was done mechanochemical treated with PVP and obtained SD as a flowable beige powder [57]. Notable differences were observed with X-ray analysis in the SD of NS and PVP: it was established that a decrease of the intensity of the crystalline phase and disappearance of peaks (reflexes) of NS took place because of a disordering of the crystal structure and the formation of the SD in amorphous state (Table 1). The micrographs showed that the PVP powder was composed of particles of a size of $0.1-0.5 \mathrm{~mm}$, while the powder of NS had a broader range of particles of 50-250 micrometers. After mechanochemical processing, the destruction of crystalline particles of NS and spherical particles of PVP occurred and aggregates of irregular shape were formed. The study of the solubility of the initial substance of NS in water showed that there was a notable change in this index. The solubility of NS substances with PVP in ratios of 1:5; 1:10, and 1:20 increased by 11.0, 19.0, and 26.7 times, respectively. The study of anthelmintic efficacy of SD demonstrated a high efficacy of them in different ratios at a dose of $20 \mathrm{mg} / \mathrm{kg} \mathrm{b} / \mathrm{w}$ at oral administration against $H$. nana in mice and M. expansa in sheep. Nevertheless, the basic NS was not effective at the same dose [58].

The modification of phenasal (synonym:niclosamide) with $\mathrm{AG}$ and $\mathrm{SiO}_{2}$ made it possible to obtain SD of various compositions with increased solubility in water, which also suggested an increase in anthelmintic activity (Table 1) [59]. The SD of Fenasal:AG (1:5) for Anoplocephalidosis of horses showed $100 \%$ efficiency at a dose of $20 \mathrm{mg} / \mathrm{kg}$ for AS, while SD of Fenasal:PVP (1:2) and Fenasal:SiO 2 (1:2) was 75-87\% active [60].

Different samples of SD that were based on praziquantel (PZQ) with disodium salt of glycyrrhizic acid $\left(\mathrm{Na}_{2} \mathrm{GA}\right)$ were obtained by mechanochemical processing and examined for some physico-chemical properties (Table 1) [61]. Based on this study:

- it was found increased solubility, reduction of particle sizes, amorphization of substance, incorporating it with micelles of glycyrrhizic acid, and high anthelmintic efficacy in reduced dose;

- the rate of diffusion of PZQ molecules from its $\mathrm{SD}$ with $\mathrm{Na}_{2} \mathrm{GA}$ is much higher than that for initial PZQ substance; and,

- the SD of PZQ was found to be a perspective anthelminthic with enhanced pharmacological activity that needs further research.

The mechanochemical technology for obtaining drugs in the form of SD was also effective with mixtures of anthelmintic substances, because the practice of using mixed preparations is an objective necessity in view of the wide range of helminths. Hence, with the simultaneous invasion of the digestive tract of sheep with Fasciols and Nematodes, the use of SD based on ABZ and TCB with PVP made it possible to achieve $100 \%$ efficiency with a single oral administration at a dose of $4.0 \mathrm{mg} / \mathrm{kg}$ for AS $(40 \mathrm{mg} / \mathrm{kg}$ for the drug) (Table 1). This dose is five times lower than the previously known therapeutic dose of the components. A mixture of ABZ and TCB substances in the same dose showed weak efficiencies-22.0 and $24.5 \%$, respectively [62]. This result was obtained due to the SD of ABZ:TCB:PVP (1:1:8) having an increased solubility of the components (ABZ by 14 times; TCB by eight times). In addition, the advantage of the drug in the form of SD is that the albendazole containing in it does not have an embryotropic effect. 
Taking the peculiarity of the parasite infestation of animals in the Altai Republic into account, parasitologists proposed developing a SD that is based on three anthelminthics (FBZ, TCB, and ivermectin/IVM/). By choosing PVP as a polymer and based on the method of mechanochemical technology, the following SD were obtained:FBZ:PVP (1:9), TCB:PVP (1:9), FBZ:IVM:PVP (1:1:9), and TCB:IVM:PVP (1:1:9) [63]. These SDs had increased solubility (in 14-29 times) (Table 1). The study of antiparasitic activity in 140 sheep showed a high efficiency of SD at doses of FBZ of 3.0 and Iver at $0.2 \mathrm{mg} / \mathrm{kg}$ on the following parasites (Strongylata, Moniesia expansa, and Melophagus ovinus), while the therapeutic doses of FBZ and IVM are 5.0 and $1.0 \mathrm{mg} / \mathrm{kg}$. SD based on TCB showed high efficacy against gastrointestinal Strongylata and $D$. dendriticum, and it was not effective against Moniesia expansa at doses of TCB 3.0 and IVM $0.2 \mathrm{mg} / \mathrm{kg}$. The parent substances FBZ and TBZ demonstrated a significantly lower efficacy in sheep helminthiasis. The high parasiticidal activity of the studied is compositions explained by increased solubility in water and bioavailability. A threefold decrease in the dosage of FBZ and TCB in drug compositions did not lead to a decrease in their anthelminthic activity [64]. Similarly, the SDs of IVM:AG (1:9) and ABZ:IVM:AG) (1:1:8) were obtained, which had increased (12 and 33 times, respectively) solubility. The study of the antiparasitic activity of these SDs in intestinal strongylitis, moniesiasis, and melophagosis of sheep (70 pcs) showed that SD in a dose of IVM equal to 0.2 and ABZ- $2.0 \mathrm{mg} / \mathrm{kg}$ (which is five times lower than the corresponding therapeutic doses of standard drugs usedin practice) was $91.4-100 \%$. At the same time, the starting substances in the same dosages turned out to be less effective [65].

On the example of mechanochemical modification of ABZ with AG, the possibility of expanding the spectrum of action of anthelmintic ABZ is shown. During joint mechanical processing of $A B Z$ and $A G$ at weight ratios of 1:10 and 1:20, SD were obtained, which, when dissolved in water, formed inclusion complexes with an increased solubility of ABZ up to 40 times (Table 1) [66]. The complexes that were obtained in this case had a new property that is not characteristic of the substance ABZ, namely, they showed high anthelmintic activity in the model of Opisthorchis felineus opisthorchiasis, which exceeded the activity of official drugs, including praziquantel. These results allowed for concluding that it is possible to create anti-opistarchosis drugs, the substances of which themselves do not have such an effect [67].

From the above material, it can be seen that the method of mechanochemical solidphase modification of medicinal substances makes it possible to obtain promising drugs in the form of SD for the animal health. This method has a number of advantages over the known ones, namely, the complete elimination of solvents from the process, one-stage operation, environmental safety, scalability, and technology flexibility.

There are many investigations with alternative methods of obtaining SD of drugs, but this is not the task of this review. It is only necessary to mention some of these works, already mentioned in paragraph 1 of this review [24-28], and they partially relate to drugs for the protection of animal health. The aim of these reviews to provide an overview of studies that address the use, in therapeutic applications, of SDs with biological activities in vitro and/or in vivo that are mainly made up of polymeric matrices, as well as to evaluate the bioactive activity of their constituents. This bibliographic survey shows that the development of solid dispersions provides benefits in the physicochemical properties of bioactive compounds, which lead to an increase in their biological potential. However, despite the reports that were found on solid dispersions, there is still a need for biological assay-based studies, mainly in vivo, to assist in the investigation and devise new applications. Therefore, studies that are based on such an approach are of great importance in enhancing and extending the use of solid dispersions in the most diverse therapeutic applications [68-70]. 
Table 1. Solid Dispersions for animal health preparations.

\begin{tabular}{|c|c|c|c|c|}
\hline Active Substance & Composition of SD & Method of Obtaining & Changes of Properties of SD & Ref. \\
\hline $\begin{array}{l}\text { Albendazole } \\
\text { (ABZ) }\end{array}$ & $\begin{array}{l}\text { ABZ:hydroxypropyl } \\
\text { b-cyclodextrin }(1: 1)\end{array}$ & freeze-drying method & $\begin{array}{c}\text { increases the bioavailability and the } \\
\text { efficacy against encapsulated Trichinella } \\
\text { larvae }\end{array}$ & [21] \\
\hline ABZ & $\begin{array}{c}\text { I.ABZ:PVP (1:1) } \\
\text { II.ABZ:hydroxypropyl- } \beta- \\
\text { cyclodextrin:l-tartaric acid } \\
(1: 1: 1)\end{array}$ & Dissolution method & $\begin{array}{l}\text { Increasing the bioavailability and } \\
\text { larvicidal activity }\end{array}$ & [22] \\
\hline $\begin{array}{l}\text { Mebendazole } \\
\quad \text { (MBZ) }\end{array}$ & $\begin{array}{l}\text { MBZ:hydroxypropyl- } \\
\text { cellulose } \\
1: 1,1: 2.5 \text { and } 1: 5\end{array}$ & $\begin{array}{l}\text { Lyophilization } \\
\text { method }\end{array}$ & $\begin{array}{l}\text { Increasing the anthelmintic effects in } \\
\text { mice against Trichinella spiralis }\end{array}$ & [24] \\
\hline Ketoconazole (KC) & KC:PVP-vynyl acetate & Melt extrusion method & Increasing the release of $\mathrm{KC}$ from SD & [26] \\
\hline Praziquantel (PZQ) & PZQ:PVP (1:1) & $\begin{array}{l}\text { Combaining } \\
\text { of mechanochemical } \\
\text { activation and the spray } \\
\text { congealing technology }\end{array}$ & $\begin{array}{l}\text { Increasing of biopharmaceutical } \\
\text { efficacy against Schistosoma mansoni }\end{array}$ & [27] \\
\hline Medamine (BMC) & BMC: pectin (1:9) & $\begin{array}{l}\text { Method of } \\
\text { mechanochemical } \\
\text { modification, } \\
\text { AGO-2-planetary } \\
\text { centrifugal mill }\end{array}$ & $\begin{array}{c}\text { I.Incresing ( } 9 \text { times) a solubility of } \\
\text { BMC and high efficacy against } \\
\text { nematodes in low concentration } \\
\text { of BMC; } \\
\text { II.New type of activity-high efficiency } \\
\text { against larval echinococcosis of } \\
\text { white rats }\end{array}$ & [38-40] \\
\hline Medamine (BMC) & $\begin{array}{c}\text { BMC: MCC }(1: 9) \\
\text { BMC: proantocianidine } \\
(1: 9)\end{array}$ & $\begin{array}{l}\text { Method of } \\
\text { mechanochemical } \\
\text { modification, } \\
\text { AGO-2 }\end{array}$ & $\begin{array}{l}\text { Increased solubility in water, better } \\
\text { permeability bio-membranes and } \\
\text { hence increased bioavailability }\end{array}$ & [41-43] \\
\hline ABZ & ABZ:AG (1:9) & $\begin{array}{c}\text { Method of } \\
\text { mechanochemical } \\
\text { modification, LE-101 rolls } \\
\text { ball mill }\end{array}$ & $\begin{array}{l}\text { Increased solubility and anthelmintic } \\
\text { activity against Trichinella spiralis, } \\
\text { Hymenolepis nana, Fasciola hepatica and } \\
\text { mixed nematodoses of sheep }\end{array}$ & {$[29,45,46]$} \\
\hline Fenbedazole (FBZ) & FBZ: PVP (1:9) & $\begin{array}{l}\text { Method of } \\
\text { mechanochemical } \\
\text { modification, LE-101 rolls } \\
\text { ball mill }\end{array}$ & $\begin{array}{l}\text { Increased solubility of FBZ, reducing } \\
\text { of particle sizes, amorphization of FBZ } \\
\text { substance and high efficacy against } \\
\text { Hymenolepis nana and Trichinella spiralis } \\
\text { infection of mice and helminthosis of } \\
\text { sheep in reduced doses }\end{array}$ & {$[47,48]$} \\
\hline ABZ & $\begin{array}{l}\text { ABZ: EL (1:9) } \\
\text { EL-extract of licorice }\end{array}$ & $\begin{array}{c}\text { Method of } \\
\text { mechanochemical } \\
\text { modification, LE-101 rolls } \\
\text { ball mill }\end{array}$ & $\begin{array}{l}\text { Increased (4-5 times higher than ABZ) } \\
\text { efficacy against Nematodirus spp., other } \\
\text { types of gastrointestinal strongylates } \\
\text { and M. expansa }\end{array}$ & [49] \\
\hline Triclabendazole (TCB) & $\begin{array}{l}\text { TCB: AG }(1: 9) \\
\text { TCB: PVP }(1: 9) \\
\text { TCB: Pectin }(1: 9) \\
\text { TCB: NaCMC }(1: 2) \\
\text { TCB: HES }(1: 9)\end{array}$ & $\begin{array}{c}\text { Method of } \\
\text { mechanochemical } \\
\text { modification, LE-101 rolls } \\
\text { ball mill }\end{array}$ & $\begin{array}{l}\text { Increased solubility of SDs ranged } \\
\text { from } 3 \text { to } 25 \text { times. } \\
\text { Efficacy against Fascioliasis of SDs in } \\
4-5 \text { timed higher than initial TCB. }\end{array}$ & [50-52] \\
\hline FBZ & $\begin{array}{c}\text { FBZ:EL:DSS } \\
\text { (1:8.9:0.1) } \\
\text { Dioctylsulfosuccinate } \\
\text { (DSS) }\end{array}$ & $\begin{array}{l}\text { Method of } \\
\text { mechanochemical } \\
\text { modification, LE-101 rolls } \\
\text { ball mill }\end{array}$ & $\begin{array}{l}\text { Incresed anthelminthic action because } \\
\text { of smaller size of FBZ, loss of } \\
\text { crystallinity, amorphization, and } \\
\text { inclusion of its molecules on the } \\
\text { surface and inside the pores of } \\
\text { polymers; the increasing in solubility } \\
\text { and permeability through biological } \\
\text { membranes }\end{array}$ & {$[53,54]$} \\
\hline
\end{tabular}


Table 1. Cont.

\begin{tabular}{|c|c|c|c|c|}
\hline Active Substance & Composition of SD & Method of Obtaining & Changes of Properties of SD & Ref. \\
\hline FBZ & FBZ:AG (1:9) & $\begin{array}{l}\text { Method of } \\
\text { mechanochemical } \\
\text { modification, LE-101 rolls } \\
\text { ball mill }\end{array}$ & $\begin{array}{l}\text { Increased (in } 18 \text { times) solubility and } \\
\text { reduced dose of FBZ shows } 100 \% \\
\text { efficiency in Dictyocaulosis, } \\
\text { Strongyloidosis and Strongylatosis of } \\
\text { digestive tract and } 98.3 \% \text { activity in } \\
\text { sheeps Trichocephalosis. }\end{array}$ & [55] \\
\hline FBZ & $\begin{array}{l}\text { FBZ:PVP:DSS } \\
\quad(1: 8.9: 0.1)\end{array}$ & $\begin{array}{l}\text { Method of } \\
\text { mechanochemical } \\
\text { modification, LE-101 rolls } \\
\text { ball mill }\end{array}$ & $\begin{array}{l}\text { Increased (in } 24 \text { times) solubility of } \\
\text { FBZ \& } 100 \% \text { efficiency in Trichinosis } \\
\text { and Hymenolepiasis in white mice and } \\
\text { gastrointestinal Strongylatosis and } \\
\text { Moniesiasis in sheeps at dose lower } \\
\text { than the recommended dose of FBZ. }\end{array}$ & [56] \\
\hline Niclosamide (NS) & $\begin{array}{l}\text { NS:PVP (1:5) } \\
\text { NS:PVP }(1: 10) \\
\text { NS:PVP }(1: 20)\end{array}$ & $\begin{array}{l}\text { Method of } \\
\text { mechanochemical } \\
\text { modification, LE-101 rolls } \\
\text { ball mill }\end{array}$ & $\begin{array}{l}\text { The solubility of SDs in ratios of } 1: 5 ; \\
1: 10 \text { and } 1: 20 \text { increased in } 11.0 ; 19.0 \text { and } \\
26.7 \text { times respectively. High efficacy of } \\
\text { SDs at a dose of } 20 \mathrm{mg} / \mathrm{kg} \text { against } H \text {. } \\
\text { nana in mice and } M . \text { expansa in sheep } \\
\text { (NS was not effective at the same dose). }\end{array}$ & {$[57,58]$} \\
\hline NS & 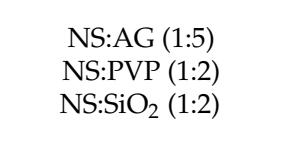 & $\begin{array}{c}\text { Method of } \\
\text { mechanochemical } \\
\text { modification, LE-101 rolls } \\
\text { ball mill }\end{array}$ & $\begin{array}{l}\text { Increased solubility and } 100 \% \\
\text { anthelmintic activity of SD (NS:AG) } \\
\text { against of anoplocephalidosis } \\
\text { of horses. }\end{array}$ & {$[59,60]$} \\
\hline PZQ & PZQ:Na ${ }_{2} \mathrm{GA}(1: 10)$ & $\begin{array}{c}\text { Method of } \\
\text { mechanochemical } \\
\text { modification, VM-I rolls } \\
\text { ball mill }\end{array}$ & $\begin{array}{l}\text { Increased solubility, reduction of } \\
\text { particle sizes, amorphization of } \\
\text { substance and high anthelmintic } \\
\text { efficacy in reduced dose. }\end{array}$ & [61] \\
\hline $\mathrm{ABZ} \& \mathrm{TCB}$ & ABZ:TCB:PVP (1:1:8) & $\begin{array}{c}\text { Method of } \\
\text { mechanochemical } \\
\text { modification, LE-101 rolls } \\
\text { ball mill }\end{array}$ & $\begin{array}{l}\text { Increased solubility of ABZ in } 14 \text { times } \\
\text { and TCB in } 8 \text { times for SD, which } \\
\text { hasn't any embryotropic effect of ABZ. } \\
\text { High efficacy against Fasciols and } \\
\text { Nematodes in dose of } 5 \text { times lower } \\
\text { than standart drugs. }\end{array}$ & [62] \\
\hline $\begin{array}{l}\text { FBZ, TCB \& ivermectin } \\
\text { (IVM) }\end{array}$ & $\begin{array}{c}\text { FBZ:PVP (1:9) } \\
\text { TCB:PVP (1:9) } \\
\text { FBZ:IVM:PVP }(1: 1: 9) \\
\text { TCB:IVM:PVP }(1: 1: 9)\end{array}$ & $\begin{array}{l}\text { Method of } \\
\text { mechanochemical } \\
\text { modification, LE-101 rolls } \\
\text { ball mill }\end{array}$ & $\begin{array}{l}\text { Increased solubility of AS (in } \\
\text { 14-29 times) and high efficacy against } \\
\text { parasites Strongylata, Moniesia expansa, } \\
\text { Melophagus ovinus in threefold decrease } \\
\text { in the dosage of FBZ and TCB. }\end{array}$ & {$[63,64]$} \\
\hline ABZ \& IVM & $\begin{array}{c}\text { IVM:AG (1:10) } \\
\text { ABZ:IVM:AG (1:1:9) }\end{array}$ & $\begin{array}{l}\text { Method of } \\
\text { mechanochemical } \\
\text { modification, LE-101 rolls } \\
\text { ball mill }\end{array}$ & $\begin{array}{l}\text { Increased (in } 12 \text { and } 33 \text { times) the } \\
\text { solubility of AS and high activity } \\
\text { against Strongylata, Moniesia expansa, } \\
\text { Melophagus ovinus in a dose of IVM } \\
\text { equal to } 0.2 \text { and ABZ-2.0 mg/kg } \\
\text { (which is } 5 \text { times lower than the } \\
\text { corresponding therapeutic doses of } \\
\text { standard drugs used in practice). The } \\
\text { initial AS in the same dosages turned } \\
\text { out to be less effective. }\end{array}$ & [65] \\
\hline ABZ & $\begin{array}{l}\text { ABZ:AG (1:10) } \\
\text { ABZ:AG (1:20) }\end{array}$ & $\begin{array}{c}\text { Method of } \\
\text { mechanochemical } \\
\text { modification, VM-I rolls } \\
\text { ball mill }\end{array}$ & $\begin{array}{c}\text { Increased of solubility of SDs and their } \\
\text { high anthelmintic activity in the model } \\
\text { of Opisthorchis felineus, which exceeded } \\
\text { the activity of official drugs, including } \\
\text { praziquantel. New biological activity } \\
\text { for ABZ. }\end{array}$ & {$[66,67]$} \\
\hline
\end{tabular}

\section{Solid Dispersions of Plant Protection Preparations}

As noted above, there are no examples of the using of SD in the field of plant protection against diseases and pests. There are only works on the effect of nanoparticles of some polymers, in particular, Chitosan, on the biophysical characteristics and growth of Robusta coffee in a greenhouse. At the same time, their influence on the content of chlorophyll, carotenoids, absorption of nutrients, and parameters of coffee growth has been shown [71]. It is also known that Fusarium graminearum is one of the most serious diseases of wheat 
in humid and warm regions, and it significantly reduces yield as well as seed quality. Chitosan nanoparticles were used in order to compare the efficacy of combating this disease [18], and their significant inhibition of both radial mycelium growth and the number of colonies formed against Fusarium graminearum was shown. An overview of works on delivery systems for Chitosan nanoparticles in agriculture is also presented [17], since Chitosan has proven to be a valuable carrier for the controlled delivery of agrochemicals and genetic materials. due to its proven biocompatibility, biodegradability, non-toxicity, and adsorption capacity.

The work on the preparation of a polymeric form of the insecticide clothianidin in a bead mill, as well as the study of its three forms, should be considered the closest to the topic under discussion on the use of SD in agriculture [20]. When studying the photodegradation and sorption of Clothianidin by soil, it was found that these processes are rather transient and it is important to know, for the future, not only the drug, but also the carriers that were used to create the drug.

As is known, tebuconazole (TBC) is one of the widely used fungicides, and so its SD we obtained using water-soluble polymers (AG, HES, PVP, pectin, etc.) to increase the solubility of TBC (Table 2) [30]. The obtained SDs were characterized by the data of $\mathrm{X}$-ray and DSC analyzes, and it was shown that joint mechanochemical treatment leads to partial disordering of the crystalline phase of TBC up to a complete loss of crystallinity. The increasing of solubility of SD (12-14 times than the initial TBC) can explain the high fungicidal activity against pathogens of root rot (Helminthosporium spp., Fusarium spp.) and other types of fungi (in particular, Penizillium spp.). At lower rates, the consumption of TBC (10-30 g/t) in comparison with the used branded drugs (e.g., Raxil SC60-the recommended rate is $60 \mathrm{~g} / \mathrm{t}$ ) confirmed that $\mathrm{SDs}$ were not only more cost effective, but also less toxic. These results made it possible to recommend SD of the composition TBC:AG (1:5) as a promising fungicidal dressing agent [72]. In order to increase the adhesion properties of this SD, a surface-active component (powder of fruits of Sapindus trifoliates) was added to it and, after $3 \mathrm{~h}$ of mechanical treatment at a module of 1:16, a beige free-flowing fine powder SD of the composition TBC:AG:surfactant (1:5:1), which easily formed a working solution for seed dressing and had increased solubility (up to 35 times) (Table 2) [73]. This protectant:

- $\quad$ had a positive effect on seed germination of soft spring wheat named "Novosibirskaya 29";

- $\quad$ effectively suppressed the growth of phytopathogenic microorganisms;

- had a positive impact on growth processes;

- $\quad$ showed a high level of healing effect on the root system of spring soft wheat grown on soil with a high density of spores of the phytopathogen Bipolaris sorokiniana; and,

- $\quad$ it was also effective in a field experiment to limit the damage to wheat plants by pathogens of common root rot.

In order to obtain the new SDs in the form of plant protection products against pests and diseases of grain crops, polysaccharides, such as GA, its sodium salt $\left(\mathrm{Na}_{2} \mathrm{GA}\right)$, and EL, were used to modify TBC [74]. Compositions in ratios of 1:5, 1:10, and 1:20 were prepared to optimize the solubility parameter of SD based on TBC and polysaccharides. Optimally, the maximum solubility was possessed by the following compositions (data on the increase in solubility are given in parentheses): TBC:GA (1:5) (34 times); TBC:Na ${ }_{2} \mathrm{GA}$ (1:5) (2.9 times); and, TBC:EL (1:10) (15.2 times). The obtained SDs reduced the crystallinity of the original TBC (but it remains), the particles with reduced crystallinity, and, having irregular shapes, their sizes are 5-10 $\mathrm{mm}$ (Table 2). The obtained SDs had increased biological activity on spring barley with a 2-5-fold decrease in the consumption rate of TBC [75].

It should be noted that the use of these polysaccharides (AG, GA, and its sodium salt) in SD preparations improves the penetration of the preparation through the plant membrane, because these polysaccharides are the closest in structure to plant membranes [76,77]. 
Table 2. Solid Dispersions for plant protection preparations.

\begin{tabular}{|c|c|c|c|c|}
\hline Active Substance & Composition of SD & Method of Obtaining & Changes of Properties of SD & Ref. \\
\hline Tebuconazole (TBC) & $\begin{array}{c}\text { TBC:AG }(1: 5) \\
\text { TBC:HES (1:2) } \\
\text { TBC:Pectin }(1: 5) \\
\text { TBC:PVP }(1: 5) \\
\text { TBC: } \beta \text {-cyclodextrin }(1: 1)\end{array}$ & $\begin{array}{l}\text { Method of } \\
\text { mechanochemical } \\
\text { modification, } \\
\text { AGO-2-planetary } \\
\text { centrifugal mill }\end{array}$ & $\begin{array}{l}\text { Increased solubility of TBC (in 2-14 times) } \\
\text { \& SD have high fungicidal activity against } \\
\text { root rot pathogens and other fungi at lower } \\
\text { doses of TBC (up to } 10 \mathrm{~g} / \mathrm{ha} \text { ) compared } \\
\text { with standart-Raxil SC ( } 60 \mathrm{~g} / \mathrm{ha}) .\end{array}$ & [30] \\
\hline TBC & $\begin{array}{c}\text { TBC:AG:surfactant } \\
(1: 5: 1)\end{array}$ & $\begin{array}{l}\text { Method of } \\
\text { mechanochemical } \\
\text { modification, LE-101 rolls } \\
\text { ball mill }\end{array}$ & $\begin{array}{l}\text { Improved physico-chemical, technological } \\
\text { and biological parameters of preparation in } \\
\text { form of SD, which demonstrated synergism } \\
\text { in accelerating the growth of cultivated } \\
\text { plants, diseases of maintaining the root } \\
\text { system and increase the yield of spring } \\
\text { wheat at lower application rates of TBC. }\end{array}$ & {$[73,78]$} \\
\hline TBC & $\begin{array}{c}\text { TBC:GA (1:5) } \\
\text { TBC:Na } 2 \text { GA (1:5) } \\
\text { TBC:EL (1:10) }\end{array}$ & $\begin{array}{l}\text { Method of } \\
\text { mechanochemical } \\
\text { modification, } \\
\text { AGO-2-planetary } \\
\text { centrifugal mill }\end{array}$ & $\begin{array}{l}\text { Reduced the crystallinity of TBC, particles } \\
\text { amorphize. Increased solubility (in } 2.9-15.2 \\
\text { times) and biological activity on spring } \\
\text { barley with a } 2-5 \text {-fold decrease in the } \\
\text { consumption rate of TBC. }\end{array}$ & {$[74,75]$} \\
\hline ТВC & TBC:Chitosan (1:10) & $\begin{array}{l}\text { Method of } \\
\text { mechanochemical } \\
\text { modification, } \\
\text { AGO-2-planetary } \\
\text { centrifugal mill }\end{array}$ & $\begin{array}{l}\text { Increased solubility (in } 1.2 \text { times) and high } \\
\text { biological efficacy against Puccinia recondita, } \\
\text { Septoria nodorum and Blumeria graminis with } \\
\text { TBC consumption decreased in } 5.5 \text { times. }\end{array}$ & [76] \\
\hline ТВC & TBC:Kelp (1:9) & $\begin{array}{l}\text { Method of } \\
\text { mechanochemical } \\
\text { modification, LE-101 rolls } \\
\text { ball mill }\end{array}$ & $\begin{array}{l}\text { Increased solubility and transmembrane } \\
\text { permeability. High efficacy against } B \text {. } \\
\text { sorokiniana and Fusarium spp. increased } \\
\text { wheat yields by } 11.4 \% \text { or } 0.28 \mathrm{t} / \mathrm{ha} \text {, } \\
\text { barley- } 11.9 \% \text { or } 0.3 \mathrm{t} / \mathrm{ha} \text {. }\end{array}$ & {$[78,79]$} \\
\hline $\begin{array}{c}\text { Benzimidazolyl- } \\
\text { MethylCarbamate } \\
\text { (BMC) }\end{array}$ & $\begin{array}{l}\text { BMC:AG (1:10) } \\
\text { BMC:PVP (1:10) } \\
\text { BMC:HES (1:10) }\end{array}$ & $\begin{array}{l}\text { Method of } \\
\text { mechanochemical } \\
\text { modification, LE-101 rolls } \\
\text { ball mill }\end{array}$ & $\begin{array}{l}\text { SD analyzed by IR, DSC and X-ray } \\
\text { methods. Increased solubility (in 1.9-21.5 } \\
\text { times) and high biological efficacy } \\
\text { againstRhizoctonia and Dry } \\
\text { rot of potato. SD influenced on morbidity, } \\
\text { development, growth of potato plants and } \\
\text { the crop yield } 1.5-4.75 \mathrm{t} / \mathrm{ha} \text {. }\end{array}$ & [80] \\
\hline TBC \& BMC & TBC: BMC:Kelp (1:1:10) & $\begin{array}{l}\text { Method of } \\
\text { mechanochemical } \\
\text { modification, LE-101 rolls } \\
\text { ball mill }\end{array}$ & $\begin{array}{l}\text { SD in the field showed a synergy of } \\
\text { biological properties, manifested in } \\
\text { accelerating growth of plants and their } \\
\text { mass, reducing the development of potato } \\
\text { rhizoctoniosis on the stems and increasing } \\
\text { productivity of crop (up to } 5.7 \mathrm{t} / \mathrm{ha} \text { ) with } \\
\text { reduced dose of AS. }\end{array}$ & [81] \\
\hline
\end{tabular}

Using Chitosan as a polymer to obtain SD of TBC:chitosan (1:10) to improve the solubility of TBC, this approach was shown to be promising. Because the obtained SD, despite that it had only a 1.2-fold increased solubility, showed high biological efficacy against Puccinia recondita, Septoria nodorum, and Blumeria graminis with a single processing of soft spring wheat, which led to an increase in grain yield by $0.55 \mathrm{t} / \mathrm{ha}$ (Table 2). It should also be noted that, in this SD, the TBC consumption decreased by 5.5 times [78].

A review [79] concerns the preparation of TBC and other fungicides (benomyl, prothioconazole, etc.) with the above and new polysaccharides (Kelp extract, Fucus vesiculosus extract, Saponins, etc.) by solid-phase mechanochemical treatment is given (Table 2). Based on the results of these studies, it can be concluded that the proposed technology of mechanochemical modification of the substances of pesticide preparations is universal and allows for it to be applied to biologically active substances and auxiliary components that differ in physical and chemical properties. In this case, the SDs of pesticide preparations are obtained with high efficiency while reducing the rate of use of the active substance $[80,81]$.

Among the various methods to protect potatoes from common diseases, the most economical and environmentally friendly is tuber dressing. Based on TBC, Thiram, and Benzimidazole fungicides, protectants (in the form of SD) have been developed for use on 
potatoes against various diseases (Table 2). The solid-phase mechanochemical modification of these fungicides with the water-soluble polymers made it possible to obtain SDs that possessed high biological activity with a reduced dosage of active substances 10 and more times due to their influence on the properties of cell membranes [82]. The biological tests of these SDs indicated a decrease in the number of tubers of patients with dry rot 1.6-2.0 times in comparison with the control variant, and they were also more effective than the standard preparation (Colfugo Super, SC 60) 1.2-1.3 times. The proposed preparations significantly reduced the development of Rhizoctoniosis in the period of sprouting 5.8-7.3 times or the plants were completely healthy, and in the budding-flowering stage 2.7-5.5 times. The preparations provided a reliable yield increase, and they also reduced the weight percentage of unsuitable tubers and significantly increased the yield of healthy tubers [83].

\section{Conclusions}

A brief review of works that are devoted to the development and application of $\mathrm{SD}$ in agriculture, in particular, for animal health and plant protection, suggests that the mechanochemical modification technology is promising for improving the properties of physiologically active substances that are used in various branches of agriculture.

The advantages of the method of mechanochemical modification of BAS the followings:

- $\quad$ one-stage, because the process of obtaining SD takes place in one stage when loading the initial components into the drum of a ball mill;

- the ability to obtain SD not only from two components, but also more (no restrictions) for which it is impossible to select solvents with a common area of dissolution;

- versatility, because the method is acceptable for a wide range of biologically active substances used in medicine, veterinary medicine, and plant protection;

- exclusion of their process of using organic solvents, which are explosive, flammable, and lead to the formation of large amounts of waste; and,

- the scalability of the process.

Funding: This research received no external funding.

Institutional Review Board Statement: Not applicable.

Informed Consent Statement: Not applicable.

Acknowledgments: Review based on investigationswere carried out on the basis of Nesmeyanov Institute of Elementoorganic compounds RAS (budgetary organization) with the support the Ministry of Science and Higher Education of the Russian Federation. Author would like to thank Colleagues from other Institutes of RF for opportunity to fulfill these investigations: Natalia G. Vlasenko, Anna A. Malyuga and Victor A. Marchenko and their teams from Center of Agrobiotechnology of SB RAS (Krasnoobsk and Barnaul); Ivan A. Arkhipov and its Laboratory from All-Russian Scientific Research Institute of Fundamental and Applied Parasitology of Animals and Plants RAS (Moscow); Alexander V. Dushkin and its Scientific Group from Institute of Solid State and Mechanochemisty of SB RAS (Novosibirsk).

Conflicts of Interest: The author declares no conflict of interest.

\section{References}

1. Chiou, W.L.; Riegelman, S. Pharmaceutical applications of Solid dispersion systems. J. Pharm. Sci. 1971, 60, 1281-1302. [CrossRef] [PubMed]

2. Kalia, A.; Poddar, M. Solid dispersions: An approach towards enhancing dissolution rate: A review. Int. J. Pharm. Sci. 2011, 3, 9-19.

3. Dhirendra, K.; Lewis, S.; Udupa, N.; Atin, K. Solid dispersions: A Review. Pak. J. Pharm. Sci. 2009, 22, 234-246. [PubMed]

4. Yadav, B.; Tanwar, E.S. Applications of solid dispersions. J. Chem. Pharm. Res. 2015, 7, 965-978.

5. Mankar, S.D.; Rachh, P.R. Solubility enhancement of poor water soluble drugs by solid dispersion: A review. J. Drug Deliv. Ther. 2018, 8, 44-49. [CrossRef]

6. Vasconcelos, T.; Sarmento, B.; Costa, P. Solid dispersions as strategy to improve oral bioavailability of poor water soluble drugs. Drug Discov. Today 2007, 12, 1068-1075. [CrossRef] [PubMed] 
7. Bobe, K.R.; Subrahmanya, C.R.; Suresh, S.; Gaikwad, D.T.; Patil, M.D.; Khade, T.S.; Gavitre, B.B.; Kulkarni, V.S.; Gaikwad, U.T. Formulation and evaluation of solid dispersion of atorvatstatin with various carriers. Pharm. Glob. (Int. J. Compr. Pharm. 2011, 2, $1-6$.

8. Shende, M.; Fiske, P. Fabrication and optimization of novel glipizide sustained release matrices for solubility and dissolution enhancement by solid dispersion through hydrophillic carriers. J. Drug Deliv. Ther. 2017, 7, 38-48. [CrossRef]

9. Nagasamy, V.D.; Saraswathi, S.; Priya, P.M.; Khan, N.I.; Kathirulla, N.; Sruthi, S. Dissolution enhancement of diacerein using water soluble carrier by solid dispersion technology. J. Drug Deliv. Ther. 2017, 7, 33-41. [CrossRef]

10. Sareen, S.; Mathew, G.; Joseph, L. Improvement in solubility of poor water-soluble drugs by solid dispersion. Int. J. Pharm. Investig. 2012, 2, 12-17. [CrossRef]

11. Kim, K.T.; Lee, J.Y.; Lee, M.Y.; Song, C.K.; Choi, J.; Kim, D. Solid Dispersions as a drug delivery system. J. Pharm. Investig. 2011, 41, 125-142. [CrossRef]

12. Leuner, C.; Dressman, J. Improving drug solubility for oral delivery using solid dispersions. Eur. J. Pharm. Biopharm. 2000, 50, 47-60. [CrossRef]

13. Jadhav, Y.L.; Parashar, B.; Ostwal, P.P.; Jain, M.S. Solid dispersion: Solubility enhancement for poorly water soluble drug. Res. J. Pharm. Technol. 2012, 5, 190-197.

14. Dalvi, P.B.; Gerange, A.B.; Ingale, P.R. Solid dispersion: Strategy to enhance solubility. J. Drug Deliv. Ther. 2015, 5, 20-28. [CrossRef]

15. Wagh, V.T.; Wagh, R.D. Solid dispersion techniques for enhancement of solubilization and biovailability of poorly water soluble drugs: A review. Int. J. Pharm. Technol. 2015, 6, 3027-3045.

16. Chaudhary, A.; Nagaich, U.; Gulati, N.; Sharma, V.K.; Khosa, R.L. Enhancement of solubilization and bioavailability of poorly soluble drugs by physical and chemical modifications: A recent review. J. Adv. Pharm. Educ. Res. 2012, 2, 32-67.

17. Kashyap, P.L.; Xiang, X.; Heiden, P. Chitosan nanoparticle based delivery systems for sustainable agriculture-A review. Int. J. Biol. Macromol. 2015, 77, 36-51. [CrossRef] [PubMed]

18. Kheiri, A.; Moosawi, J.S.A.; Malihipour, A.; Saremi, H.; Nikkhah, M. Application of chitosan and chitosan nanoparticles for the control of Fusarium head blight of wheat (Fusarium graminearum) in vitro and greenhouse. Int. J. Biol. Macromol. 2016, 93, 1261-1272. [CrossRef]

19. Chhipa, H. Nanofertilizers and nanopesticides for agriculture. Environ. Chem. Lett. 2017, 15, 15-22. [CrossRef]

20. Kah, M.; Walch, H.; Hofmann, T. Environmental fate of nanopesticides: Durability, sorption and photodegradation of nanoformulated clothianidin. Environ. Sci. Nano 2018, 5, 882-889. [CrossRef]

21. Castillo, J.A.; Palomo-Canales, J.; Garcia, J.J.; Lastres, J.L.; Bolas, F.; Torrado, J.J. Preparation and characterization of albendazole $\beta$-cyclodextrin complexes. Drug Dev. Ind. Pharm. 1999, 25, 1241-1248. [CrossRef] [PubMed]

22. Kalaiselvan, R.; Mohanta, G.P.; Madhusudan, S.; Manna, P.K.; Manavalan, R. Enhancement of bioavailability and anthelmintic efficacy of albendazoleby solid dispersion and cyclodextrin complexation techniques. Pharmazie 2007, 62, 604-607.

23. Kalaiselvan, R.; Mohanta, G.P.; Manna, P.K.; Manavalan, R. Inhibition of albendazole crystallization in poly(vinylpyrrolidone) solid molecular dispersions. Pharmazie 2006, 61, 618-624. [PubMed]

24. García-Rodriguez, J.J.; Torre-Iglesias, P.M.; Vegas-Sánchez, M.C.; Torrado-Durán, S.; Bolás-Fernández, F.; Torrado-Santiago, S. Changed crystallinity of mebendazole solid dispersion: Improved anthelmintic activity. Int. J. Pharm. 2011, 403, 23-28. [CrossRef] [PubMed]

25. Kumar, S.; Gupta, S.K. Pharmaceutical solid dispersion technology: A strategy to improve dissolution of poorly water-soluble drugs. Recent Pat. Drug Deliv. Formul. 2013, 7, 111-121. [CrossRef] [PubMed]

26. Kanaujia, P.; Wai, G.K.; Widjaja, E.; Hanefeld, A.; Fischbach, M.; Maio, M.; Tan, R.B.H. Nanoparticle formation and growth during in vitro dissolution of ketoconazole solid dispersion. J. Pharm. Sci. 2011, 7, 2876-2885. [CrossRef]

27. Albertini, B.; Perissutti, B.; Bertoni, S.; Zanolla, D.; Franceschinis, E.; Voinovich, D.; Lombardo, F.; Keiser, J.; Passerin, N. Combining mechanochemistry and spray congealing for new praziquantel pediatric formulations in schistosomiasis treatment. Int. J. Mol. Sci. 2019, 20, 1233. [CrossRef] [PubMed]

28. Oliveira, V.S.; Almeida, A.S.; Albuquerque, I.S.; Duarte, F.C.; Queiroz, B.C.S.H.; Converti, A.; Lima, A.A.N. Therapeutic applications of solid dispersions for drugs and new molecules: In vitro and in vivo activities. Pharmaceutics 2020, $12,933$. [CrossRef]

29. Khalikov, S.S.; Chistyachenko, Y.S.; Dushkin, A.V.; Meteleva, E.S.; Polyakov, N.E.; Arkhipov, I.A.; Varlamova, A.I.; Glamazdin, I.I.; Danilevskaya, N.V. Creation of high-efficiency anthelmintic preparations based on intermolecular complexes of active substances with water-soluble polymers, including polysaccharides. Chem. Sustain. Dev. 2015, 23, 567-577. [CrossRef]

30. Khalikov, S.S.; Dushkin, A.V.; Davletov, R.D.; Evseenko, V.I. Creation of innovative fungicides based on Tebuconazole with the involvement of mechanochemical processes. Fundam. Res. 2013, 12, 2695-2700.

31. Dushkin, A.V.; Suntsova, L.P.; Khalikov, S.S. Mechanochemical technology for increasing the solubility of medicinal substances. Fundam. Res. 2013, 2, 448-455.

32. Tkachenko, M.L.; Zhnyakina, L.E.; Kosmynin, A.S. Physicochemical investigation of Paracetamol—Caffeine solid mixtures. Pharm. Chem. J. 2003, 37, 430-432. [CrossRef]

33. Khalikov, S.S.; Dushkin, A.V. Strategies for solubility enhancement of anthelmintics (review). Pharm. Chem. J. 2020, 54, 504-508. [CrossRef] 
34. Dushkin, A.V.; Meteleva, E.S.; Tolstikova, T.G.; Tolstikov, G.A.; Polyakov, N.E.; Neverova, N.A.; Medvedeva, E.N.; Babkin, V.A. Mechanochemical preparation and pharmacological activities of water-soluble intermolecular complexes of arabinogalactan with medicinal agents. Rus. Chem. Bull. 2008, 57, 1299-1307. [CrossRef]

35. Khalikov, S.S.; Lokshin, B.V.; Ilyin, M.M.; Varlamova, A.I.; Musaev, M.B.; Arhipov, A.I. Methods for obtaining solid dispersions of drugs and their properties. Rus. Chem. Bull. 2019, 68, 1924-1932. [CrossRef]

36. Khalikov, S.S.; Avdeeva, A.V.; Aripov, K.N. Mechanochemical reactions of N-acylation of n-toluidine by carboxylic acids. Uzb. Chem. J. 1995, 2, 74-76. (In Russian)

37. Dushkin, A.V.; Karntovskaia, L.M.; Chabueva, E.N.; Pavlov, S.V.; Kobrin, V.S.; Boldyrev, V.V.; Kobrina, V.N.; Grasdhannikov, A.E.; Knjazev, V.V.; Starichenko, V.F. Solid-phase mechanochemical synthesis of fluoroaromatic compounds. Synth. Commun. 2001, 31, 1041-1045. [CrossRef]

38. Khalikov, S.S.; Kutlymuratov, A.P.; Kristallovich, E.L.; Abdullaev, N.D.; Khodzhaeva, M.A.; Sadykov, T.; Aripov, K.N. Modification of the solubility of benzimidazole drugs on mechanical treatment with pectins. Chem. Nat. Compd. 1995, 31, 460-464. [CrossRef]

39. Lopatina, N.S.; Dzhabarova, V.I.; Lebedeva, M.N. The pharmacokinetics of medamine and its solid polymer form (medapec) in experimental larval alveolar echinococcosis cotton rats. Med. Parasitol. Parasit. Dis. 2000, 3, 37-40. (In Russian)

40. Dzhabarova, V.I.; Kovalenko, F.P.; Lebedeva, M.N. Experimental study of the suitability of Medapec as the drug of choice for treatment of echinococcosis. Med. Parasitol. Parasit. Dis. 2004, 4, 40-44. (In Russian)

41. Khalikov, S.S.; Zhuravleva, G.P.; Larin, P.P.; Kogan, L.P.; Aripov, K.N. Study of the properties of microcrystalline cellulose and its polycomplex with a benzimidazole drug after mechanical activation. Chem. Nat. Compd. 1995, 31, 251-253. [CrossRef]

42. Burkhanova, N.D.; Yugai, S.M.; Khalikov, S.S.; Turganov, M.M.; Muratova, S.A.; Nikonovich, G.V.; Aripov, K.N. Interaction of drugs with microcrystalline cellulose at the molecular and supermolecular levels. Chem. Nat. Compd. 1997, 33, 340-346. [CrossRef]

43. Khalikov, S.S.; Pominova, T.Y.; Avgeeva, A.V.; Kuliev, Z.A.; Aripov, K.N. Mechanicochemical interaction of plant proanthocyanidins with drugs. Chem. Nat. Compd. 1995, 31, 184-186. [CrossRef]

44. Campbell, W.C. Benzimidazoles: Veterinary uses. Parasitol. Today 1990, 6, 130-133. [CrossRef]

45. Chistyachenko, Y.S.; Meteleva, E.S.; Pakharukova, M.Y.; Katokhin, A.V.; Khvostov, M.V.; Varlamova, A.I.; Glamazdin, I.I.; Khalikov, S.S.; Polyakov, N.E.; Arkhipov, I.A.; et al. Physicochemical and pharmacological study of the newly synthesized complex of albendazole and polysaccharide arabinogalactan from larch wood. Curr. Drug Deliv. 2015, 12, 477-490. [CrossRef] [PubMed]

46. Pat RF 2546535. 2014. Available online: www.fips.ru (accessed on 10 April 2015).

47. Arkhipov, I.A.; Khalikov, S.S.; Sadov, K.M.; Dushkin, A.V.; Meteleva, E.S.; Varlamova, A.I.; Odoevskaya, I.M.; Danilevskaya, N.V. Influence of mechanochemical technology on anthelmintic efficacy of the supramolecular complex of fenbendazole with polyvinylpyrrolidone. J. Adv. Vet. Anim. Res. 2019, 6, 133-141. [CrossRef]

48. Pat RF 2558922. 2014. Available online: www.fips.ru (accessed on 10 August 2015).

49. Varlamova, A.I.; Arkhipov, I.A.; Khalikov, S.S.; Arisov, M.V.; Sadov, K.M.; Dushkin, A.V. Increasing the biological activity of benzimidazoles based on the supramolecular nanoscale delivery system with licorice extract against helminthiasis. IOP Conf. Ser. Earth Environ. Sci. 2020, 548, 042012. [CrossRef]

50. Musaev, M.B.; Khalikov, M.S.; Milenina, M.V.; Dzhamalova, A.Z.; Bersanova, H.I.; Iriskhanov, I.V. Commission and field testing of efficacy of the supramolecular complex of triclabendazole «Triclafascid» against cattle fascioliasis. Rus. J. Parasitol. 2018, 12, 76-80. [CrossRef]

51. Medvedeva, E.N.; Babkin, V.A.; Ostroukhova, L.A. Arabinogalactan of larch-Properties and prospects of use: A review. Chem. Plant Raw Mater. 2003, 1, 27-37.

52. Pat RF 2640482. 2016. Available online: www.fips.ru (accessed on 9 January 2018).

53. Varlamova, A.I.; Movsesyan, S.O.; Arkhipov, I.A.; Khalikov, S.S.; Arisov, M.V.; Kochetkov, P.P.; Abramov, V.E.; Ilyin, M.M.; Lokshin, B.V. Biological activity and pharmacokinetic behavior of fenbendazole integrated into a supramolecular delivery system with licorice extract and sodium dioctyl sulfosuccinate. Biol. Bull. 2020, 47, 565-574. [CrossRef]

54. Pat RF 2709019. 2019. Available online: www.fips.ru (accessed on 13 December 2019).

55. Varlamova, A.I.; Limova, Y.V.; Sadov, K.M.; Sadova, A.K.; Belova, E.E.; Radionov, A.V.; Khalikov, S.S.; Chistyachenko, Y.S.; Dushkin, A.V.; Skira, V.N.; et al. Efficacy of the supramolecular complex of Fenbendazole against nematodiasis in sheep. Rus. J. Parasitol. 2016, 35, 76-81.

56. Varlamova, A.I.; Arkhipov, I.A.; Khalikov, S.S.; Sadov, K.M. Efficiency of fenbendazole on the basis of nanosized supramolecular delivery systems with polyvinylpyrrolidone and dioctylsulphosuccinate sodium in the cases of helminthosis. Rus. J. Parasitol. 2019, 13, 56-63. [CrossRef]

57. Arkhipov, I.A.; Sadov, K.M.; Limova, Y.V.; Sadova, A.K.; Varlamova, A.I.; Khalikov, S.S.; Dushkin, A.V.; Chistyachenko, Y.S. The efficacy of the supramolecular complexes of Niclosamide obtained by mechanochemical technology and targeted delivery against cestode infection of animals. Vet. Parasitol. 2017, 246, 25-29. [CrossRef] [PubMed]

58. Pat RF 2588368. 2015. Available online: www.fips.ru (accessed on 27 June 2016).

59. Limova, Y.V.; Sadov, K.M.; Kanatbaev, S.G.; Arkhipov, I.A. Anthelmintic efficacy of Phenasalum based on supramolecular drug delivery systems (DDS) at monieziasis in cattle. Rus. J. Parasitol. 2016, 36, 223-227. [CrossRef]

60. Limova, Y.V.; Sadov, K.M.; Korogodina, E.V.; Arkhipov, I.A.; Khalikov, S.S. Anthelmintic efficiency of new Phenasal formulations based on supramolecular, nanoscale drug delivery systems for anoplocephalidosis in horses. Rus. J. Parasitol. 2017, 40, 188-191. 
61. Arkhipov, I.; Khalikov, S.; Dushkin, A.; Sadov, K.; Meteleva, E.; Arisov, M.; Varlamova, A. Anthelmintic efficacy of supramolecular complex of praziquantel obtained by mechanochemical technology. Iran. J. Parasitol. 2020, 15, 364-373. [CrossRef]

62. Lagereva, E.V.; Abramov, V.E.; Musaev, M.B.; Khalikov, S.S. Efficacy of supramolecular complex based on Albendazole and Triclabendazole against fasciolosis and gastro-intestinal nematodosis of sheep. Rus. J. Parasitol. 2019, 13, 82-88. [CrossRef]

63. Marchenko, V.A.; Khalikov, S.S. Supramolecular complexes of drugs for parasitic sheep infestations. IOP Conf. Ser. Earth Environ. Sci. 2020, 548, 082006. [CrossRef]

64. Marchenko, V.A.; Khalikov, S.S.; Vasilenko, Y.A.; Ilyin, M.M.; Kravchenko, I.A. Innovative anthelmintic based on mechanochemical technology and their efficacy against parasitic infection of sheeps. J. Adv. Vet. Anim. Res. 2020, 7, 8718-8725. [CrossRef]

65. Pat RF 2699799. 2019. Available online: www.fips.ru (accessed on 9 November 2019).

66. Mordvinov, V.A.; Pakharukova, M.Y.; Katokhin, A.V.; Dushkin, A.V.; Chistyachenko, Y.S.; Belousov, A.I.; Khvostov, M.V.; Zhukova, N.A.; Khalikov, S.S.; Tolstikova, T.G.; et al. Siberian opisthorchiasis. Biology, prevalence and development of new drugs for its treatment. Chem. Sustain. Dev. 2015, 23, 579-584. [CrossRef]

67. Pat RF 2545797. 2013. Available online: www.fips.ru (accessed on 10 April 2015).

68. Kumari, B.; Bishnoi, K.H. Solid dispersions: Its types and mechanism of enhancement of solubility by solid dispersions. J. Pharma Res. 2019, 3, 65-71.

69. Baghel, S.; Cathcart, H.; O'Reilly, N.J. Polymeric amorphous solid dispersions: A review of amorphization, crystallization, stabilization, solid-state characterization, and aqueous solubilization of biopharmaceutical classification system class II drugs. J. Pharm. Sci. 2016, 105, 2527-2544. [CrossRef] [PubMed]

70. Haser, A.; Zhang, F. New strategies for improving the development and performance of amorphous solid dispersions. AAPS PharmSciTech 2018, 19, 978-990. [CrossRef] [PubMed]

71. Van, S.N.; Minh, H.D.; Anh, D.N. Study on chitosan nanoparticles on biophysical characteristics and growth of robusta coffee in greenhouse. Biocatal. Agric. Biotechnol. 2013, 2, 289-294.

72. Pat RF 2469536. 2011. Available online: www.fips.ru (accessed on 20 December 2012).

73. Khalikov, S.S.; Teplyakova, O.I.; Vlasenko, N.G.; Khalikov, M.S.; Evseenko, V.I.; Dushkin, A.V. Application of Arabinogalactan for improvement of technological and biological properties of grain culture protectants. Chem. Sustain. Dev. 2015, 23, 591-599.

74. Meteleva, E.S.; Evseenko, V.I.; Teplyakova, O.I.; Khalikov, S.S.; Polyakov, N.E.; Apanasenko, E.I.; Dushkin, A.V.; Vlasenko, N.G. Nanopesticides based on supramolecular Tebuconazole complexes for the treatment of cereal seeds. Chem. Sustain. Dev. 2018, 26, 279-294. [CrossRef]

75. Pat RF 2619249. 2016. Available online: www.fips.ru (accessed on 12 May 2017).

76. Selyutina, O.Y.; Apanasenko, I.E.; Khalikov, S.S.; Polyakov, N.E. Natural poly- and oligosaccharides as novel delivery systems for plant protection compounds. J. Agric. Food Chem. 2017, 10, 6582-6587. [CrossRef] [PubMed]

77. Selyutina, O.Y.; Khalikov, S.S.; Polyakov, N.E. Arabinogalactan and glycyrrhizin based nanopesticides as novel delivery systems for plant protection. Environ. Sci. Pollut. Res. 2020, 27, 5864-5872. [CrossRef]

78. Meteleva, E.S.; Evseenko, V.I.; Teplyakova, O.I.; Kulagin, O.V.; Selyutina, O.Y.; Polyakov, N.E.; Dushkin, A.V.; Vlasenko, N.G. Innovative means of protecting spring wheat based on Chitohan obtained by Mechanochemistry methods. Chem. Sustain. Dev. 2020, 28, 57-65. [CrossRef]

79. Vlasenko, N.G.; Khalikov, S.S.; Burlakova, S.V. Flexibile techhology of protectants for grain seeds. IOP Conf. Ser. Earth Environ. Sci. 2020, 548, 082003. [CrossRef]

80. Pat RF 2592616. 2015. Available online: www.fips.ru (accessed on 27 July 2016).

81. Pat RF 2646625. 2016. Available online: www.fips.ru (accessed on 6 March 2018).

82. Khalikov, S.S.; Malyuga, A.A.; Chulikova, N.S. Complex preparations for the protection potato on the basis of tebuconazole. J. Agric. Sci. Technol. A 2019, 9, 338-343. [CrossRef]

83. Pat RF 2602447. 2015. Available online: www.fips.ru (accessed on 20 November 2016). 